Studia i Materiały, 2/2016 (22), cz. 2: 23-32

\title{
Rola innowacji miękkich w badaniach innowacyjności przedsiębiorstw z sektorów niskotechnologicznych na przykładzie sektora spożywczego
}

\author{
Magdalena Klimczuk-Kochańska*
}

\begin{abstract}
Artykut dotyczy problematyki innowacyjności podmiotów działających $w$ sektorach niskich technologii. Podjęto $w$ nim rozważania na temat przyczyn niskiej obecności przedsiębiorstw $z$ takich sektorów $w$ statystykach dotyczacych innowacyjności. Przedstawiono podstawowe definicje innowacji. Ukazano specyfike sektora spożywczego jako jednego z kluczowych sektorów gospodarki światowej. Następnie przedstawiono sposoby wprowadzana innowacji miękkich przez przedsiębiorstwa sektora spożywczego.
\end{abstract}

Nadesłany: 20.11.2016 | Zaakceptowany do druku: 20.12.2016

Słowa kluczowe: innowacje miękkie, sektory niskotechnologiczne, sektor spożywczy, badania innowacyjności.

\section{The Role of the Soft Innovation in the Research of Low-Tech Sectors on the Example of Food Industry}

The study refers to the issue of innovation entities operating in the low-tech sectors. It discusses the reasons for the low presence of companies from this kind of sectors in the statistics on innovation. The article presents the basic definitions of innovation. It shows the specificity of the food sector as one of the key sectors of the global economy. Next, reference is made to the current distribution of innovations and the specifics of soft innovation are presented, including an attempt to identify ways of soft innovations introduction by food businesses.

Keywords: soft innovations, low technology sectors, food industry, innovation analysis.

Submitted: 20.11.2016 | Accepted: 20.12.2016

JEL: L5, O31, O32

\footnotetext{
* Magdalena Klimczuk-Kochańska - dr, Zakład Teorii i Metod Organizacji, Wydział Zarządzania, Uniwersytet Warszawski.

Adres do korespondencji: Zakład Teorii i Metod Organizacji, Wydział Zarządzania, Uniwersytet Warszawski, ul. Szturmowa 1/3, 02-678 Warszwa; e-mail: mklimczuk@wz.uw.edu.pl.
} 


\section{Wprowadzenie}

Sukces przedsiębiorstwa wymaga wprowadzania na rynek nowych produktów i usług, które byłyby atrakcyjne dla potencjalnego odbiorcy. Oznacza to konieczność podejmowania przez firmy działań w zakresie opracowywania nowych produktów, procesów, wprowadzania zmian organizacyjnych czy marketingowych. Przedsiębiorstwa spożywcze często dokonują zmian w swojej ofercie czy sposobie działania, jednak są one na tyle małe, że nie dostrzegają ich statystyki mające na celu badanie innowacyjności różnych sektorów. Można uznać, że sposoby mierzenia innowacji w sektorach tzw. niskotechnologicznych (ang. low technology sectors) nie są adekwatne do ich specyfiki, gdyż skierowane są raczej na pomiar innowacyjności w sektorach wysokotechnologicznych (ang. high technology), na które najczęściej zwrcają uwagę zarówno decydenci, jak i badacze. Niewątpliwie sektory takie dają możliwości większego rozwoju technologii i postępu technicznego. Nie zmienia to jednak faktu, że sektory niskotechnologiczne, takie jak spożywczy, są również bardzo ważne dla gospodarek różnych krajów, a ich poziom innowacyjności przekłada się na konkurencyjność i ogólne powodzenie firm - producentów na rynku.

W odniesieniu do powyższych rozważań jako cel niniejszego opracowania przyjęto wykazanie, że innowacje miękkie to ważny rodzajów innowacji prowadzonych przez przedsiębiorstwa sektora spożywczego. Zaprezentowano kolejno ogólne pojęcie innowacji i ukazano specyfikę analizowanego sektora $\mathrm{z}$ perspektywy możliwości prowadzenia działalności innowacyjnej. Następnie omówiono koncepcję innowacji miękkich (ang. soft innovations), jako brakującego elementu w systemie analiz poziomu innowacyjności w sektorach niskotechnologicznych. Przeprowadzona analiza może stać się przyczynkiem do dalszych rozważań na temat stanu konkurencyjności i innowacyjności sektorów niskich technologii, nie tylko w Polsce, Unii Europejskiej (UE), lecz także na świecie.

\section{Innowacje - podstawowe pojęcia}

Niektórzy autorzy twierdzą, że innowacje to wszystko, co jest postrzegane przez człowieka jako nowe - praktyka, rzecz - niezależnie od obiektywnej nowości (Rogers, 1983, s. 11). A.H. Van de Ven (1986, s. 590-591) definiuje innowacje jako rozwój nowych idei, ich przekształcenie i wdrożenie w praktyce.

Jak wynika z literatury przedmiotu, innowacja nie jest równoznaczna z pomysłem (wynalazkiem) (ang. invention). Zdaniem C. Freemana (1982) pierwsze $z$ tych pojęć oznacza zmianę wynikającą z wprowadzenia nowości, zaś drugie na opracowaniu nowego urządzenia czy procesu. P. Senge (1990) wskazał na cechę innowacji, jaką jest możliwość powielania danej idei na znaczącą skalę. Natomiast przez wynalazek rozumiał ideę, która jest wynikiem badań podstawowych i nie wyszła poza mury laboratorium.

W drugim wydaniu Podręcznika Oslo Manual z 1997 roku, opracowanego w ramach Organizacji Współpracy Gospodarczej i Rozwoju (ang. Organization for Economic Co-operation and Development, OECD), pt. The measurement of scientific and technological activities: Proposed guidelines for collecting and interpreting technological innovation data, za innowacje uznano jedynie tzw. innowacje techniczne, czyli nowe lub istotnie ulepszone produkty i procesy (OECD, 1997). Innowacje techniczne często mają charakter radykalny (przełomowy). K.B. Dahlin i D.M. Behrens (2005) uważają, że radykalność innowacji wynika $\mathrm{z}$ technicznej istoty produktu. Ich zdaniem innowacje radykalne to takie, które spełniają trzy obligatoryjne warunki: są nowatorskie, unikalne, a przede wszystkim wywierają znaczący wpływ na przyszłe technologie, gdyż wyznaczają kierunek ich rozwoju.

W kolejnej edycji Podręcznika Oslo Manual z 2005 roku wyróżniono cztery grupy innowacji: produktowe, procesowe - składające się na innowacje techniczne i organizacyjne oraz marketingowe - stanowiące tzw. innowacje nietechniczne (OECD, 2005). Zapisano przy tym, że produkty, procesy i metody są innowacjami, jeśli sa nowe lub istotnie ulepszone przynajmniej z punktu widzenia wdrażającego je przedsiębiorstwa, czyli mogą być to rozwiązania nowe zarówno w skali świata, rynku, branży, jak i przedsiębiorstwa. Wspomniane tu zmiany w projekcie i (lub) konstrukcji produktów polegają na zmianie formy i wyglądu produktów nie prowadzącej do zmiany ich cech funkcjonalnych ani użytkowych (OECD, 2005, s. 52). 
Jak zauważa C.M. Christensen (2010, s. 21), innowacje takie poprawiają efektywność dotychczasowych produktów, która jest oceniana przez głównych klientów na dużych rynkach. Ich źródłem moga być zarówno własne prace badawczo-rozwojowe $(B+R)$, jak i umiejętne wychwycenie sygnałów płynących $\mathrm{z}$ rynku, na którym użytkownicy dóbr i usług zgłaszają swoje oczekiwania i potrzeby poprzez dokonanie zakupu lub rezygnację $\mathrm{z}$ niego bądź w drodze badań marketingowych. Zatem to właśnie użytkownicy produktów i procesów sa współtwórcami tego typu innowacji (Freeman, 1968).

Powyższy podział wskazuje, że innowacje to coś więcej niż tylko działalność wysokotechnologiczna i wiążące się $\mathrm{z}$ nią radykalne zmiany. Niezbędne jest więc uwzględnienie $\mathrm{w}$ analizach poziomu innowacyjności różnych sektorów, w szerszym zakresie innowacji nietechnicznych, mimo że zmiany te nie mają tak spektakularnego przebiegu jak współcześnie ma to miejsce chociażby w sektorze technologii informacyjno-komunikacyjnych (Heidenreich 2009; Mendonça, 2014).

\section{Specyfika działalności innowacyjnej w sektorze spożywczym}

Przegląd literatury z zakresu innowacyjności wskazuje, że zarówno badania w tym obszarze, jak i realizowana polityka w wielu krajach, w bardzo silnym stopniu skoncentrowane sa na sektorach wysokich technologii i opartych na wiedzy naukowej. Wielu badaczy krytykuje jednak takie podejście (Tödtling i Trippl, 2005; Tunzelmann i Acha, 2005; Hirsch-Kreinsen, 2008; Hirsch-Kreisen, Jacobson 2008). Twierdzą, że tradycyjne sektory odgrywają ważną rolę we współczesnej gospodarce i zasadne jest rzucenie nowego światła na działania w nich zachodzące, w tym również na wprowadzanie innowacji. Jak wynika $\mathrm{z}$ badań T. Sandvena i in. (2005, s. 57), przedsiębiorstwa niskotechnologiczne wytwarzaja nowe produkty i procesy, które wpływają w większym stopniu na wzrost ekonomiczny krajów OECD niż przemysły wysokozaawansowane technologicznie. Wyniki innych badań pokazuja, że ponad $50 \%$ wszystkich innowacyjnych firm w UE nie realizuje działalności badawczo-rozwojowej (B+R) (Som, 2012). Nasuwa się zatem wniosek, że nie można lekceważyć wagi sektorów tzw. niskotechnologicznych przy analizie innowacyjności krajów, regionów czy przedsiębiorstw.

Sektor produkcji żywności jest prawdopodobnie jednym z najstarszych przemysłów gospodarki na świecie. Należy do kluczowych sektorów ze względu na swoją strategiczną działalność dla każdego kraju - dostarczenie żywności dla ludności. Produkty, które wytwarzają przedsiębiorstwa spożywcze, można rozpatrywać m.in. w kontekście: podstawowych surowców, które są używane do produkcji (w tym m.in. mięsa, ryb, owoców), funkcji produktów (np. żywność funkcjonalna - ang. functional food, nutraceutyki), poziomu nowości produktów (np. „nowa” żywność - ang. novel food, tradycyjna żywność) czy stosowanych metod produkcji (np. organiczne, modyfikowane genetycznie). Jak wynika z powyższego, produkty sektora spożywczego moga mieć bardzo różny charakter. Niektóre przedsiębiorstwa sektora stosuja tradycyjne metody produkcji, które nieraz nawet nie moga zostać w żadnym stopniu zmienione, jeśli producent chce otrzymać odpowiednie oznakowanie swoich wyrobów (np. chronione oznaczenie geograficzne). Sa też producenci, którzy wytwarzaja wyroby $\mathrm{z}$ zastosowaniem innowacyjnych metod opartych na badaniach naukowych (np. żywność funkcjonalna). Generalnie jednak sektor ten cechuje niski poziom technologii i tak właśnie jest klasyfikowany (Hirsch-Kreinsen i in., 2006; Kirner i in., 2009, Mark-Herbert, 2004; Esposti i in., 2007, s. 44-45).

Taka sytuacja w sektorze pozwala twierdzić, że podmioty w nim działające można podzielić na dwie grupy ze względu na sposób transferu technologii niezbędnej do wytwarzania innowacyjnych wyrobów. Według skali K. Pavitta (1984) wyróżnia się firmy o intensywnej skali produkcji (ang. scale intensive) oraz należące do podmiotów zdominowanych przez dostawców technologii (ang. supplier dominated). W pierwszych z nich źródłem innowacji jest zorganizowana struktura podziału zadań, w której tworzone są często działy badawczo-rozwojowe. Podmioty takie same projektują, budują i zarządzają systemami produkcji. Natomiast druga grupe reprezentują podmioty, które absorbują technologie ucieleśnione w nabytych maszynach i urządzeniach. Transfer technologii 
z zagranicy odbywa się z wykorzystaniem mechanizmu importu dóbr kapitałowych. Korzyści z transferu polegają na podniesieniu umiejętności zawodowych związanych z pozyskaniem dostępu do nowej wiedzy. Zatem podmioty te nie tworzą własnych przewag innowacyjnych, a raczej skupiają się na ich pozyskaniu od dostawców i częstym naśladowaniu działań innych podmiotów.

Odnajduje to potwierdzenie w wynikach badań Community Innovation Survey (CIS) organizowanych przez Komisję Europejską. Pokazują one, że szczególnie niskie jest wykorzystanie patentów, jak również udział w obrocie nowymi produktami na rynku przez podmioty sektora spożywczego (Eposti, 2009, s. 141-144; Ciliberti i in., 2015).

Niski udział patentów może wynikać przede wszystkim z ogólnych trudności stojących na drodze podmiotów sektora do uzyskania tego typu praw ochronnych na produkty żywnościowe, które są często oparte na recepturach (Leis i in., 2011) Okazuje się bowiem, że chociaż żywność i napoje, a także sposoby ich wytwarzania mogłyby podlegać opatentowaniu, np. produkty o niskiej zawartości tłuszczu lub wyroby, które ze względu na kształt lub skład mają widoczne zalety, to jednak większość $\mathrm{z}$ nich nie spełnia kryteriów, jakim podlegają produkty do opatentowania. Przede wszystkim chodzi o kryterium nowości i braku oczywistości danego rozwiązania. $\mathrm{Z}$ tego powodu nie mogą być opatentowane na przykład efekty smakowe, które, chociaż mają zasadnicze znaczenie dla rozróżnienia wyrobów firmy i sukcesu gospodarczego danego rodzaju żywności, nie mają zdolności patentowej (Leis i in., 2011, s. 22)

Inny wskaźnik innowacyjności, jakim są wydatki na działalność badawczo-rozwojową, również w przypadku analizowanego sektora znajduje się na bardzo niskim poziomie (EC, 2015, s. 34). Zasadniczo inwestycje $\mathrm{w}$ innowacje przede wszystkim realizowane sa przez duże firmy, w tym szczególne zaangażowanie zauważa się pośród działających w sektorze międzynarodowych korporacji. Prowadzą one działalność badawczo-rozwojową skupioną na opracowywaniu nowych procesów i nowych produktów. Jednak duże firmy, które generują około $51,5 \%$ obrotów całego sektora w UE, stanowią mniej niż 1\% ogólnej liczby podmiotów w europejskim sektorze pro- dukcji żywności. Firmy mające mniej niż 10 pracowników, czyli mikroprzedsiębiorstwa, nie są w ogóle uwzględniane w statystykach takich jak CIS, chociaż większość podmiotów, które działaja w analizowanym sektorze na terenie UE to firmy tzw. mikro. Stanowia one około $78,0 \%$ wszystkich przedsiębiorstw w UE-27 zajmujących się produkcją żywności i napojów. Łącznie podmioty te generują $6,9 \%$ obrotów sektora. Oznacza to, że dane CIS nie dostarczają pełnych informacji o innowacyjności sektora spożywczego (Leis i in., 2011, s. 23-24).

Co więcej: postrzeganie innowacyjności przez pryzmat poziomu wydatków na badania i rozwój jest niewystarczające również dlatego, że wiele innowacji w sektorze spożywczym ma charakter inkrementalny (np. Baregheh i in., 2012). Poza tym, jak pokazują wyniki badań sektora spożywczego, producenci artykułów spożywczych często wprowadzali innowacje marketingowe. Innowacje te polegaja bardzo czesto na drobnych usprawnieniach w produktach, które nie są ujęte $\mathrm{w}$ formalnie poniesionych wydatkach na badania i rozwój (Juchniewicz, 2011, s. 159-164; Esposti i in., 2007, s. 31).

Ponadto warto zwrócić uwage na fakt, że historycznie rzecz biorac, opracowanie i stosowanie wskaźników innowacyjności było wynikiem działań instytucjonalnych i kształtowania strategii rozwoju krajów, czy regionów (Smith, 2006, s. 150-152). W związku z tym liczba patentów i poziom wydatków na działalność badawczo-rozwojową oraz analiza wynalazków, stanowiła podstawę analiz statystycznych z zakresu nauki i techniki. Ze wskaźników patentowych przede wszystkim chętnie korzystali i korzystają prawnicy i inżynierowie, dla których są one cennym źródłem informacji o innych zgłoszonych produktach, czy technologiach (Mendonça, 2014). Natomiast wydatki na działalność badawczorozwojową były i są bardzo często przede wszystkim wynikiem rosnacej presji ze strony rządów różnych państw na inwestycje w nowa wiedzę high-tech. Jednocześnie nie pozwalają na analizę niektórych rodzajów zmiennych, takich jak kapitał ludzki, w tych sektorach, w których niezbędne jest zastosowanie odpowiedniej, specyficznej wiedzy w danej dziedzinie.

Jak twierdzi K. Smith (2006, s. 150), wskaźniki innowacyjności nie zostały 
zaprojektowane przez socjologów i badaczy, a przecież procesy innowacyjne ewoluują, a z nimi powinny zmieniać się normy oraz procedury dotyczące działalności innowacyjnej. Poza tym trzeba brać pod uwagę fakt, że innowacja jest trudna do zmierzenia. Popularnie stosowane wskaźniki pomiaru innowacyjności zbliżają się do tego w różnym zakresie. Niektóre nadaja się do analizy tylko wybranych branż - chociażby wydatki na $\mathrm{B}+\mathrm{R}$ i liczba patentów to dobre mierniki badania poziomu innowacyjności dużych firm farmaceutycznych.

Należy zgodzić się ze P. Stonemanem (2010, s. 114), że informacje na temat patentów czy wydatków na $\mathrm{B}+\mathrm{R}$ nie muszą dostarczać pełnego obrazu sytuacji w przemyśle takim jak spożywczy, który ciągle przedstawia nowe warianty danego rodzaju produktów i zmienia je w odpowiedzi na oczekiwania konsumentów. Niezbędne jest zatem poszukiwanie innych sposobów prowadzenia analiz poziomu innowacyjności w sektorach niskotechnologicznych.

\section{Tworzenie wartości dla \\ klienta podstawą innowacji w sektorze spożywczym}

Innowacje często są wynikiem konkurowania przedsiębiorstw przede wszystkim jakością przetworzonych produktów oraz szeroka oferta nowych czy ulepszonych produktów. Jest to wynikiem prowadzenia działań zorientowanych na klienta, czyli marketingu. Podejście takie jest zgodnie z definicją P.F. Druckera (1992, s. 42), który postrzega innowacje jako zmianę wartości dla konsumenta. Oznacza to nie tylko tworzenie nowych lub lepszych produktów, które prowadzi do nowych korzyści dla nabywcy, czy niższej ceny przekładającej się na zwiększenie dostępności do produktu, ale także tworzenie nowych potrzeb lub znalezienie nowych zastosowań dla starego produktu (Drucker, 1994, s. 54-55).

Jeśli, jak twierdzi wielu autorów (np. Stoneman, 2010; Heidenreich, 2009), na znaczeniu zyskują innowacje marketingowe, to oznacza to, że menedżerowie firm sektora spożywczego powinni wziąć pod uwagę akceptację cech produktów i sposobów ich wytwarzania ze strony konsumentów. Występuje tu bardzo wiele drażliwych kwestii, jak chociażby zagadnienia bezpieczeństwa żywności, etyki i odpowiedzialności ekologicznej. Konsumenci żywności czę- sto bardziej akceptują wprowadzanie zmian o charakterze inkrementalnym, bazujących na produktach i metodach produkcji już znanych i stosowanych od dłuższego czasu. $\mathrm{Z}$ drugiej strony niektóre innowacje, np. dotyczące redukcji tkanki tłuszczowej, zmniejszenia użycia szkodliwych dla zdrowia konserwantów i dodatków, jak również kwestii ochrony środowiska, są wysoce pożądane.

Dla licznej grupy obecnych lub potencjalnych klientów przepisy żywnościowe często niewystarczająco regulują niektóre kwestie. Problemy pojawiają się np. w kwestii prawnego uregulowania niektórych rodzajów żywności leczniczej, która wykracza poza żywność funkcjonalną. Co więcej, zdarza się i tak, że sami naukowcy często spierają się między sobą w kwestiach takich jak badania bezpieczeństwa żywności genetycznie modyfikowanej, czy co do stosowania niektórych dodatków do żywności i ich wpływu na zdrowie człowieka. Kontrowersje budzi też wprowadzenie nowych rodzajów surowców, jak chociażby stosowanie w produkcji żywności białek pochodzących z owadów, co nie jest popularne w Europie. To wszystko sprawia, że konsumenci często nie mają dostatecznych podstaw do podejmowania decyzji, co jest szczególnie ważne przy wprowadzaniu na rynek produktów innych niż tradycyjne.

Obawy przed wpływem nowych metod produkcji czy dodatków do żywności, na organizm człowieka prowadzą do sytuacji, gdy nie ma akceptacji różnych grup interesariuszy na wprowadzanie innowacji o charakterze bardziej radykalnym i technicznym (np. mięso na hamburgera wyhodowane w laboratorium). Jednocześnie jednak innowacje marketingowe bardzo często nie budzą większych obaw ze strony konsumentów, a co więcej nie tylko często nie wymagają znaczących nakładów finansowych na ich wprowadzenie, ale i jednocześnie są zdecydowanie mniej ryzykowane dla przedsiębiorstw.

Tworzenie wartości dla klienta nie zawsze jednak było ważne. J.A. Schumpeter (1960) całkowicie lekceważył konsumenta jako czynnik innowacji. W jego rozumieniu konsumpcja ma charakter bierny - odbiorcy jedynie spożywają dostarczane na rynek dobra. A. Marshall (1920, s. 86; za: Swan, 2009, s. 194) w przeciwieństwie do J.A. Schumpetera podkreślał, że gospo- 
darka napędzana jest przez konsumentów, którzy chcą nabywać towary o coraz wyższej jakości. Takie ich zachowanie daje możliwości wprowadzania innowacji. Powyższa propozycja A. Marshalla stała się podstawą do rozważań prowadzonych przez K.J. Lancastera (1966, s. 134). Twierdził on, że wszystkie warianty określonego dobra posiadają tę samą funkcję kosztów i podobną cenę, a różnią się odmienną proporcją cech charakterystycznych produktu, takich jak np. styl, smak lub zapach, które każdy odbiorca produktu może postrzegać subiektywnie. Na wybory konsumenta wpływają zatam nie tyle ilości, ile jakości dobra (Lancaster, 1966, s. 132). Użyteczność konsumenta jest więc funkcją atrybutów danego dobra, które obejmuja zarówno różne warianty estetyczne, jak i intelektualne. Podsumowując, w ramach tzw. hipotezy hedonistycznej (ang. hedonic hypothesis) K.J. Lancaster (1966, s. 134) wskazuje na trzy główne kwestie: (1) dobro per se nie wpływa na użyteczności dla konsumenta, zaś charakterystyki, jakie ono posiada mają wpływ na użyteczność dobra dla konsumenta - zatem podstawą wyborów ekonomicznych są właśnie te cechy dobra, a nie dobra jako takie; (2) dobro posiada więcej niż jedną cechę charakterystyczną i wiele takich cech jest dzielonych przez więcej niż jedno dobro; oraz (3) dobra w połączeniu mogą posiadać właściwości różne od tych dotyczących każdego z dóbr z osobna.

$Z$ biegiem czasu już współcześni autorzy, jak na przykład P.F. Drucker (1992), uznali innowacje za pojęcie bardziej społeczne niż techniczne, a zatem takie, które polega na zmianie wartości i zaspokojenia konsumenta przez wykorzystanie określonych zasobów. P.F. Drucker (1992, s. 42) określa innowację jako szczególne narzędzie przedsiębiorców, za pomocą którego ze zmiany czynią oni okazję do podjęcia nowej działalności gospodarczej lub świadczenia nowych usług. Jego zdaniem innowacja ani nie musi polegać na zmianach technicznych, ani nie musi być materialna. Może ona mieć miejsce w projektach, działaniach marketingowych, produktach, w cenie lub usłudze dla klienta, organizacji lub metodach zarzadzania. Sugeruje przy tym, że innowacje we wszystkich kategoriach, jakie zdefiniował J.A. Schumpeter, moga mieć wpływ na tworzenie wartości dla klienta.

Także J. Altkorn (2006, s. 141) uwzględnia rolę klienta $\mathrm{w}$ tworzeniu innowacji.
Wymienia on innowacje oryginalne (absolutne), które dotyczą produktów całkowicie nowych, zaspokajających potrzeby dotychczas niezaspokojone oraz innowacje nieoryginalne (naśladownicze). Innowacje oryginalne zaspokajają zarówno potrzeby wcześniej znane, ale nie zaspokajane, jak i potrzeby wcześniej nieodczuwane, które zostały rozbudzone u konsumenta poprzez prowadzenie odpowiednich działań marketingowych. Innowacje nieoryginalne polegają zaś na dochodzeniu do rozwiązania już wcześniej przez kogoś opracowanego lub zastosowanego w praktyce. Moga też polegać na imitacji już istniejących produktów czy procesów. Są to produkty lepiej lub gorzej zaspokajające potrzeby zaspokajane dotad przez inne produkty.

P. Stoneman (2010) wprowadza pojęcie innowacji miękich (ang. soft innovation), które definiuje jako zmiany o charakterze estetycznym i intelektualnym, w produktach lub procesach. Powstałe w ten sposób innowacje maja wpływ bardziej na zmysłowa, intelektualną lub estetyczną percepcję konsumenta niż na aspekt funkcjonalności danego produktu (NESTA, 2009, s. 21). P. Stoneman zdefiniował to pojęcie i wyjaśniał jego różne aspekty, co nie oznacza jednak, że propozycja zwrócenia uwagi na aspekty estetyczne innowacji jest zupełnie nowym nurtem w badaniach nad innowacjami.

Na cechy estetyczne wskazywali bowiem również inni autorzy. G. Bianchi i F. Bortolotti (1996) używają pojęcia „innowacje pozorne" (ang. formal innovation) na zmiany, które zmieniają formę produktu bez koniecznych zmian w funkcji produktów i metod produkcji. Uważają, że nowa forma wywyższa estetyczne lub symboliczne treści danego produktu.

J.A. Marzal oraz E.T. Esparza (2007, s. 34-35) twierdzą, że w wyniku zmian estetycznych produkt może być postrzegany jako zupełnie inny, a nawet zastępować wcześniejsze produkty. Główne cechy innowacji estetycznej (ang. aesthetic innovation) to: zwiększenie postrzeganej wartości produktu; spełnianie wymagań klientów dotyczących np. smaku; niedostarczanie nowej funkcjonalności dla produktu; i niezmienianie sposobu, w jaki produkt jest używany. Zwracają również uwagę na analogię innowacji estetycznych do innowacji projektowych (ang. design innovation) i innowacji stylistycznych (ang. stylistic innovation). 
Wydaje się, że definicja innowacji marketingowych przedstawiona w Podręczniku Oslo w 2005 roku częściowo uwzględnia innowacje miękkie. Wspomniane w nim zmiany w projekcie i (lub) konstrukcji produktów polegają na zmianie formy i wyglądu produktów, nieprowadzącej do zmiany ich cech funkcjonalnych ani użytkowych (OECD, 2005, s. 52). Do tej grupy zalicza się także zmiany w opakowaniu produktu spożywczego. Innym przykładem innowacji marketingowej jest wprowadzenie znaczących zmian w formie, wyglądzie lub smaku produktu, np. napój typu cola o smaku cytrynowym.

Głównym wyróżnikiem innowacji marketingowych jest wprowadzenie zmian w zakresie funkcji lub zastosowań produktu. Wyroby i usługi o cechach funkcjonalnych lub użytkowych, znaczaco udoskonalonych względem istniejących produktów, to innowacje produktowe. Natomiast wprowadzenie nowej koncepcji marketingowej wymagającej znaczącej zmiany w konstrukcji istniejącego produktu jest innowacją marketingowa (OECD, 2005, s. 56). Nie mamy jednak do czynienia $\mathrm{z}$ innowacją produktową, jeśli funkcjonalność danego produktu nie zmieniła się. Oznacza to, że żywność produkowana $\mathrm{z}$ zastosowaniem innych niż do tej pory rodzajów dodatków funkcjonalnych (np. dodatek błonnika czy kwasu Omega 3 do jogurtu, woda mineralna z kolagenem), stanowi innowację w obrębie produktu, natomiast pierwsze wprowadzenie nowego kształtu opakowania (np. kartonik czy butelka na jogurt pitny) przeznaczonego dla nowej grupy klientów lub majacego nadać produktowi większa ekskluzywność, jest innowacją marketingową.

Podsumowując: innowacje miękkie maja charakter nietechnologiczny, przy czym nie wszystkie zmiany nietechnologiczne sa innowacjami miękkimi. Innowacje miękkie należy traktować jako odrębny rodzaj innowacji, które polegają na zmianach w walorach estetycznych, a w konsekwencji i w funkcjonalności produktu.

\section{Sposoby wprowadzania innowacji miękkich w sektorze spożywczym}

W sektorze spożywczym innowacje estetyczne można rozumieć jako modyfikacje produktów, które uzyskuje się poprzez ich różnicowanie (ang. product differentiation) lub rozszerzenie linii produktów (ang. line extension). Rozwiązania te są dobrze znane w kontekście marketingu, jednak nie sa zaliczane do działań o charakterze innowacji z punktu widzenia klasyfikacji OECD.

Różnicowanie produktów można definiować jako występowanie dóbr w wielu odmianach, które zaspokajaja te same potrzeby nabywcy, ale nie w ten sam sposób. Poszczególne odmiany stanowią więc substytuty, które $\mathrm{z}$ punktu widzenia nabywcy nie sa wobec siebie doskonałe. Zróżnicowanie dotyczy postrzegania jakości i kosztów wytworzenia poszczególnych wariantów produktu (Anglin, 1992). P. Stoneman proponuje podzielenie działań w zakresie innowacji miękkich na wertykalne (pionowe) i horyzontalne (poziome) (Stoneman, 2010, s. 29).

Dwa produkty są zróżnicowane pionowo, jeżeli nabywcy przy danej cenie wybierają raczej ten drugi produkt. W takim przypadku wyroby te moga być obiektywnie sklasyfikowane przez konsumentów pod względem jakości, czyli każdy potencjalny nabywca może bez problemu zidentyfikować odmiany danego produktu najbardziej pożądane $\mathrm{z}$ jego punktu widzenia. W zasadzie każdy nabywca mający do wyboru zróżnicowane jakościowo warianty określonego dobra, chciałby posiadać wariant o najwyższej jakości. Zwykle jednak na rynku występuje sytuacja, w której modele lepsze jakościowo sa droższe. To sprawia, że nie wszyscy konsumenci mogą zakupić dobro przez nich preferowane, czyli to o najwyższej jakości. Dokonują więc wyboru produktu spośród odmian, które są dla nich dostępne finansowo. W efekcie rozkład popytu na zróżnicowane pod względem jakości dobra jest zdeterminowany poziomem indywidualnych dochodów. Modyfikacje produktów o charakterze pionowym oznaczaja więc powstawanie innowacji, które nie tworzą nowych kategorii ani nowych rynków. Występują zawsze w obrębie tej kategorii produktowej, w której powstała idea produktu (Kotler i Trias de Bes, 2004). Przykładem może być wprowadzenie soku pomarańczowego typu premium jako sprzedawanego po cenie wyższej niż standardowy odpowiednik. Czym innym jest „oryginalny” serek wiejski z Piątnicy, a czym innym jego podróbka. Jakość może być zatem postrzegana jako sposób różnicowania, który daje producentowi tego wyrobu przewagę konkurencyjną w danym segmencie rynku. Zasadac 
jest, że lepsze produkty mają wyższą cene, zarówno z powodu wyższych kosztów produkcji wynikających chociażby z wyższej jakości surowców, dłuższego procesu produkcyjnego, większej liczby badań potwierdzających wpływ produktu na zdrowie, jak również z większych oczekiwanych korzyści dla klientów. Oznacza to najczęściej, że konsumenci, którzy nie mają wyrobionej opinii w danej kwestii, mogą na podstawie ceny danego produktu wnioskować o jego jakości. Wolą zapłacić wyższą cenę, bo liczą na to, że w parze z nią idzie wyższa jakość produktu.

W przypadku zróżnicowania poziomego produktów mamy do czynienia $z$ dobrami o charakterze jednorodnym z punktu widzenia producenta, które są postrzegane przez nabywców ze względu na cechy niezwiązane z jakością, takie jak smak, zapach, kolor (różne wersje kolorystyczne tego samego produktu), styl (produkty ekologiczne, organiczne, tradycyjne). I chociaż wszystkie warianty określonego dobra posiadają tę samą funkcję kosztów i podobną cenę, to z punktu widzenia konsumenta różnią się odmienną proporcją cech charakterystycznych (Lancaster, 1966). W tym przypadku warianty produktu nie mogą zostać obiektywnie ocenione pod względem jakości. Jako przykład można podać różne odmiany wody mineralnej, które cechuje inne źródło wydobycia, czy inna procentowa zawartość różnych składników mineralnych. Na rynku jest też wiele artykułów mlecznych o różnej zawartości tłuszczu, czy innym smaku, przy czym na przykład lody truskawkowe wcale nie są „lepsze” od czekoladowych i na odwrót, a gałka lodów w obu smakach ma tę samą cenę.

Innym sposobem na wprowadzenie innowacji miękkich, jaki proponuje P. Stoneman, jest rozszerzenie linii produktów. W marketingu wyróżnia się wiele typów rozszerzeń liniowych, takich jak nowości kontra starsze linie produktu, produkty niemarkowe a markowe lub produkty pod marka własna. Rozszerzenie linii o nowy produkt oznacza wprowadzenie co najmniej jednego innego produktu niż ten już od jakiegoś czasu będący w ofercie firmy. Jest to zwykle związane $\mathrm{z}$ wprowadzeniem nowych rozmiarów (jogurty w opakowaniach $150 \mathrm{~g}, 400 \mathrm{~g}$ ) czy „modeli” (batony Mars w postaci lodów) (Stoneman, 2010, s. 115). Na ogół takie rozszerzenia obejmują zmiany o charakterze adaptacyjnym.
Przedstawione powyżej propozycje sposobów wprowadzania innowacji tzw. miękkich przez przedsiębiorstwa spożywcze pokazują, że są to działania, które faktycznie przedsiebiorstwa często realizuja a więc nie są dla nich czymś kompletnie obcym czy niemożliwym do wprowadzania. Generalnie jednak nie są one określane mianem innowacji. W kontekście przeprowadzonych analiz można jednak uznać, że zaproponowane przez P. Stonemana pojęcie innowacji miękkich wydaje się mieć swoje uzasadnienie do stosowania w przypadku sektora spożywczego.

\section{Wnioski}

Faktyczny poziom innowacyjności przedsiębiorstw sektora spożywczego jest najprawdopodobniej znacznie wyższy niż ten wyliczany za pomocą tak popularnych wskaźników jak np. liczba patentów czy wysokość wydatków na B+R. Brak jednak wytycznych, jak analizować tę innowacyjność.

Jednocześnie można dostrzec wzrost zainteresowania tematyką innowacji w sektorach tradycyjnych o charakterze niskotechnologicznym, na co ma wpływ fakt, że obecnie innowacyjność jest daleko idąca koncepcją, która nie ogranicza się do wielkości możliwości technologicznych, a obejmuje również zdolności reorganizacji strategii, wiedzy i działań marketingowych.

Przeprowadzona powyżej analiza pokazuje, że pojęcie innowacji miękkich jest szersze od ogólnie przyjętej definicji innowacji marketingowych. Uzupełnienie zestawu rodzajów innowacji o innowacje miękkie pozwala na uwzględnienie aspektów estetycznych, które wydają się jednymi $\mathrm{z}$ najważniejszych $\mathrm{w}$ wyborach dokonywanych przez konsumentów. Zmiany tego typu są nie tylko ważne w badaniach nad poziomem innowacyjności i konkurencyjności sektora spożywczego, ale i innych chociażby sektorów kreatywnych.

Inną kwestią pozostaje odpowiedź na pytanie, jakich mierników użyć, by w sposób obiektywny możliwe było przeprowadzenie analizy innowacyjności sektora spożywczego z uwzględnieniem innowacji miękkich. W literaturze przedmiotu można spotkać się $\mathrm{z}$ pewnym propozycjami w tym zakresie. Przedstawiane są analizy statystyk znaków towarowych (ang. trademarks), czy liczby zarejestrowanych wzorów przemysło- 
wych (ang. design registration). Wydaje się jednak, że powyższe wskaźniki nie wyczerpują tematu pomiaru innowacji miękkich. Zestaw mierników innowacyjności mógłby zostać uzupełniony chociażby o wskaźnik liczby odmian danego produktu różniących się jakością, wskaźnik liczby odmian danego produktu różniących się innymi cechami niezwiązanymi z jakością (np. styl, smak, kolor), jak również wskaźnik szerokości danej linii produktowej. Należy podjąć próby weryfikacji użyteczności powyższych mierników. Warto przy tym mieć na uwadze, że powyższa propozycja nie wyczerpuje możliwości dalszych prac nad wskaźnikam innowacyjności w sektorach niskotechnologicznych. Co więcej: należy zwrócić uwage, że badań w tym obszarze, jak do tej pory jest niewiele i wydaje się zasadne prowadzenie ich nie tylko przez badaczy z obszaru zarządzania, ale także z innych dziedzin, w tym między innymi socjologów, co może przyczynić się do wypracowania nowych metod pomiaru innowacyjności sektorów niskotechnologicznych, które nadal pozostają ważnym źródłem wzrostu większości gospodarek na całym świecie.

\section{Bibliografia}

Altkorn, J. (red.) (2006). Podstawy marketingu. Kraków: Instytut Marketingu.

Anglin, P.M. (1992). The relationship between models of horizontal and vertical differentiation. Bulletin of Economic Research, 44(1), 1-20.

Baregheh, A., Rowley, J., Sambrook, S. i Davies, D. (2012). Food sector SMEs and innovation types. British Food Journal, 114(11), 1640-1653, http:// dx.doi.org/10.1108/00070701211273126.

Bianchi, G. i Bortolotti, F. (1996). On the concept of formal innovation. Referat przedstawiony na European Regional Science Association, 36th European Congress. Zurich: ETH.

Brännback, M. i Wiklund, P. (2001). A new dominant logic and its implications for knowledge management: A study of the Finnish food industry. Knowledge and Process Management, 8(4), 197-206, http://dx.doi.org/10.1002/kpm.123.

Christensen, C.M. (2010). Przetomowe innowacje. Warszawa: Wydawnictwo Naukowe PWN.

Ciliberti, S., Bröring, S. i Martino, G. (2015). Drivers of innovation in the European food industry: Evidences from the Community Innovation Survey. International Journal on Food System Dynamics, 6(2), 175-190, http://dx.doi.org/10.18461/ijfsd. v6i3.635.
Dahlin, K.B. i Behrens, D.M. (2005). When is an invention really radical? Defining and measuring technological radicalness. Research Policy, 34(5), 717-737, http://dx.doi.org/10.1016/j. respol.2005.03.009.

Drucker, P.F. (1994). Praktyka zarządzania. Kraków: Akademia Ekonomiczna.

Drucker, P.F. (1992). Innowacja i przedsiębiorczość. Praktyka i zasady. Warszawa: PWE.

EC (European Commission). (2015). The 2015 EU industrial R\&D investment scoreboard. Luxembourg: Publications Office of the European Union.

Esposti, R. (2009). Solving the controversy between functional and natural food: Is agri-food production becoming modular? W: A. Lindgreen, M.K. Hingley, J. Vanhamme, The crisis of food brands: sustaining safe, innovative and competitive food supply. Surrey i Farnham: Gower Publishing Ltd.

Esposti, R., Lucatelli., S. i Peta E.A. (2007). Innovations strategies and consumption trends in Italy: A focus on the agro-food sector. Materiali UVAL. Analisi e Studi, 15.

Firlej, K. i Żmija, D. (2014). Transfer wiedzy i dyfuzja innowacji jako źródto konkurencyjności przedsiębiorstw przemystu spożywczego $w$ Polsce. Kraków: Wydawnictwo UEK i Fundacja UEK.

Freeman, C. (1968). Chemical process plant: Innovation and the world market. National Institute Economic Review, 45, 29-51.

Freeman, C. (1982). The economics of industrial innovation. Cambridge: MIT Press.

Heidenreich, M. (2009). Innovation patterns and location of European low-medium-technology industries. Research Policy, 38(3), 483-494, http:// dx.doi.org/10.1016/j.respol.2008.10.005.

Hirsch-Kreinsen, H. (2008). „Low-technology”. A forgotten sector in innovation policy. Jour nal of Technology Management and Innovation, 3(3), 11-20, http://dx.doi.org/10.4067/S071827242008000100002.

Hirsch-Kreinsen, H. i Jacobson, D. (red.). (2008). Innovation in low-tech firms and industries. Cheltenham i Northampton: Edward Elgar.

Hirsch-Kreinsen, H., Jacobson, D. i Robertson, P.L. (2006). 'Low-tech' industries: Innovativeness and development perspectives - a summary of a European Research Project. Prometheus: Critical Studies in Innovation, 24(1), 3-21, http://dx.doi. org/10.1080/08109020600563762.

Juchniewicz, M. (2011). Innowacje nietechnologiczne w przemyśle spożywczym. Roczniki Naukowe Stowarzyszenia Ekonomistów Rolnictwa i Agrobiznesu, 13(2), 159-164.

Kirner, E., Kinkel, S. i Jaeger, A. (2009). Innovation paths and the innovation performance of lowtechnology firms: An empirical analysis of German 
industry. Research Policy, 38(3), 447-458, http:// dx.doi.org/10.1016/j.respol.2008.10.011.

Kotler, Ph. i Trias de Bes, F. (2004). Marketing lateralny. Warszawa: PWE.

Lancaster, K.J. (1966). A new approach to consumer theory. Journal of Political Economy, 74(2), 132-157, http://dx.doi.org/10.1086/259131.

Leis, M., Gijsbers, G. i van der Zee, F. (2011) Sectoral innovation watch: Food and drinks sector: Final sector report. DG Enterprise and Industry, European Commission.

Mark-Herbert, C. (2004). Innovation of a new product category - functional foods. Technovation, 24(9), 713-719, http://dx.doi.org/10.1016/S01664972(02)00131-1.

Marshall, A. (1920). Principles of Economics. London: Macmillan.

Marzal, J.A. i Esparza, E.T. (2007). Innovation assessment in traditional industries: A proposal of aesthetic innovation indicators. Scientometrics, 72(1), 33-57, http://dx.doi.org/10.1007/s11192-007-1708-x.

Mendonça, S. (2014). National adaptive advantages: Soft innovation and marketing capabilities in periods of crisis and change. W: A.A.C. Teixeira, E. Silva i R.P. Mamede (red.), Structural change, competitiveness and industrial policy: Painful lessons from the European periphery. London: Routledge.

Mowery, D. i Rosenberg, N. (1979). The influence of market demand upon innovation: A critical review of some recent empirical studies. Research Policy, 8(2), 102-153.

NESTA (National Endowment for Science, Technology and the Arts.) (2009). Soft innovation: Towards a more complete picture of innovative change. London.

OECD. (1997). The measurement of scientific and technological activities: Proposed guidelines for collecting and interpreting technological innovation data: Oslo Manual. Paris.

OECD. (2005). Guidelines for collecting and interpreting innovation data: Oslo Manual. Paris.

Pavitt, K. (1984). Sectoral patterns of technical change: Towards a taxonomy and a theory.
Research Policy, 13(6), 343-373, http://dx.doi org/10.1016/0048-7333(84)90018-0.

Rogers, E.M. (1983). Diffusion of innovations. New York: Free Press, London: Collier Macmillan.

Sandven, T., Smith, K. i Kaloudis, A. (2005). Structural change, growth and innovation: The roles of medium and low-tech industries, 1980-2000. W: H. Hirsch-Kreinsen, D. Jacobson i S. Læstadius (red.), Low-tech innovation in the knowledge economy. Frankfurt am Main: Peter Lang Publishing.

Schumpeter, J.A. (1960). Teoria rozwoju gospodarczego. Warszawa: PWN.

Senge, P. (1990). The Fifth Discipline. New York: Doubleday / Currency.

Smith, K. (2006). Measuring innovation. W: J. Fagerberg, D.C. Mowery i R.R. Nelson (red), The Oxford Handbook of Innovation. Oxford: Oxford University Press, http://dx.doi.org/10.1093/oxfor dhb/9780199286805.003.0006.

Som, O. (2012). Innovation without R\&D: Heterogeneous innovation patterns of non-R\&D-performing firms in the German manufacturing industry. Wiesbaden: Springer Gabler, http://dx.doi org/10.1007/978-3-8349-3492-5_5.

Stoneman, P. (2010). Soft innovation: Economics, product aesthetics, and the creative industries. Oxford: Oxford University Press, http://dx.doi. org/ 10.1093/acprof:oso/9780199572489.001.0001.

Swan, G.M.P. (2009). The economics of innovation: An introduction. Cheltenham: Edward Elgar Publishing.Tödtling, F. i Trippl, M. (2005). One size fits all? Towards a differentiated regional innovation policy approach. Research Policy, 34(8), 1203-1219, http://dx.doi.org/10.1016/j.respol.2005. 01.018 .

Tunzelmann, von N., Acha, V. (2005). Innovation in "low-tech" industries. W: J. Fagerberg, D.C. Mowery i R.R. Nelson (red.), The Oxford Handbook of Innovation. Oxford: Oxford University, http://dx.doi. org/10.1093/oxfordhb/9780199286805.003.0015.

Van de Ven, A.H. (1986). Central problems in the management of innovation. Management Science, 32(5), 590-607. 